\title{
Debt-free cardiac health
}

\author{
Victor Farah", Mark Doyle, Geetha Rayarao, Diane V Thompson, Ronald B Williams, June A Yamrozik, Moneal Shah, \\ Robert W Biederman
}

From 19th Annual SCMR Scientific Sessions

Los Angeles, CA, USA. 27-30 January 2016

\section{Background}

Predicting cardiac prognosis and outcome is important. As the heart progresses towards failure, it is known that the ventricular-vascular coupling (VVC) progresses from the optimal range ( 0.5 to 1.2$)$ to values as high as 10 in severe failure. However, even hearts close to failure may exhibit a $\mathrm{VVC}$ in the normal range and thus its future predictive value is low. Here we consider the cardiac energy usage derived from cardiovascular magnetic resonance (CMR) to better utilize VVC data. To accomplish this we consider the difference between internal energy $\left(\mathrm{E}_{\text {Internal }}\right)$ and external energy $\left(E_{\text {External }}\right)$ which we term energy debt $\left(E_{\text {Debt }}\right)$.

\section{Objective}

To establish the relationship between $\mathrm{E}_{\text {Debt }}$ and VVC and show that $\mathrm{E}_{\text {Debt }}$ adds to the assessment of cardiac health.

\section{Methods}

CMR volumetric image data were collected in patients $(\mathrm{n}=90)$ undergoing functional evaluation to measure; end-systolic volume (ESV), end-diastolic volume (EDV), stroke volume (SV), blood pressure and heart rate. From the end-systolic pressure volume relationship (ESPVR) (Figure 1) the $\mathrm{E}_{\text {Internal }}$ is calculated as:

$\mathrm{E}_{\text {Internal }}=1 / 2$ ESV.Pes (equ 1)

Where $\mathrm{P}_{\mathrm{es}}$ is considered to be approximated to the mean arterial pressure:

MAP $=[$ DBP $+1 / 3($ SBP-DBP) $]($ equ 2)

The $\mathrm{E}_{\text {External }}$ is calculated as:

$\mathrm{E}_{\text {External }}=\mathrm{SV} \times \mathrm{P}_{\mathrm{es}}$ (equ 3)

VVC is calculated as:

$\mathrm{VVC}=\mathrm{ESV} / \mathrm{SV}$ (equ 4)

$E_{\text {Debt }}$ is calculated as:

$\mathrm{E}_{\text {Debt }}=\mathrm{E}_{\text {Internal }}-\mathrm{E}_{\text {External }}$ (equ 5)

By substitution and arrangement:

$E_{\text {Debt }}=1 / 2 P_{\text {es }} \times S V x($ VVC-2) (equ 6)

\section{Results}

The plot of VVC vs. $E_{\text {Debt }}$ is fitted to a log curve (Figure 2). As is apparent from equ 6 and Figure 2, when the $E_{\text {Debt }}$ transitions from positive to negative the VVC exceeds 2. Further, note the high steepness of the curve for values when $E_{\text {Debt }}$ is positive.
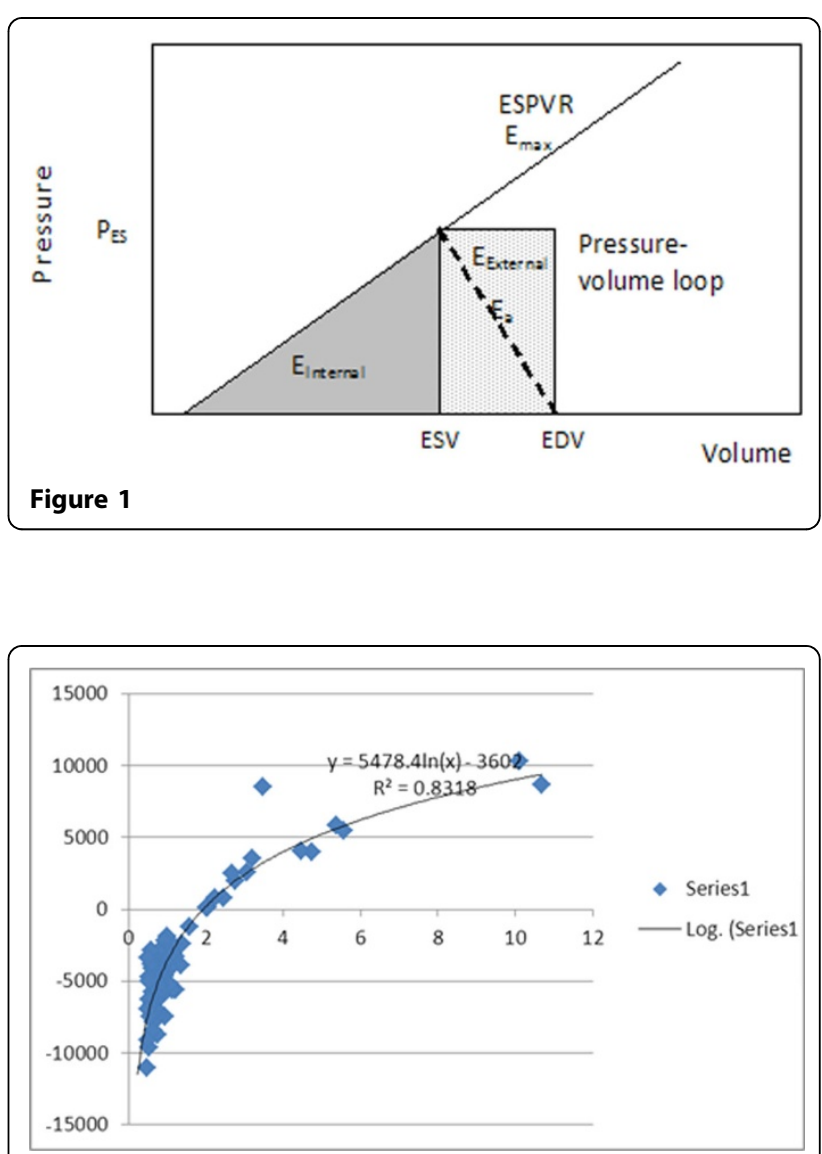

Figure 2 


\section{Conclusions}

Here we consider the net difference between internal and external ventricular work derived from non-invasive PV loops acquired during routine CMR exams. By regarding internal work as a negative burden and external work as a positive expression of cardiac function, we show that hearts with a net energy debt cross over to failure, while hearts with a net positive energy expression function normally. Thus, $\mathrm{E}_{\text {Debt }}$ provides additional information, since even when the VVC is within the optimal working range, the heart may be close to crossing the debt line, masquerading dysfunction. Once crossed, the curve indicates that rapid acceleration to a high VVC may imminently follow. Importantly, we show that even hearts with a healthy VVC value, heretofore believed to be advantageous, may be close to failure by the net energy debt criteria.

Published: 27 January 2016

doi:10.1186/1532-429X-18-S1-P247

Cite this article as: Farah et al:: Debt-free cardiac health. Journal of

Cardiovascular Magnetic Resonance 2016 18(Suppl 1):P247.

Submit your next manuscript to BioMed Central and take full advantage of:

- Convenient online submission

- Thorough peer review

- No space constraints or color figure charges

- Immediate publication on acceptance

- Inclusion in PubMed, CAS, Scopus and Google Scholar

- Research which is freely available for redistribution

Submit your manuscript at www.biomedcentral.com/submit 